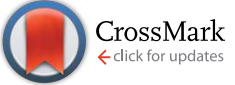

Cite this: RSC Adv., 2017, 7, 10660
Received 2nd December 2016 Accepted 30th January 2017

DOI: $10.1039 / c 6 r a 27684 a$

rsc.li/rsc-advances

\title{
8-Styryl-substituted coralyne derivatives as DNA binding fluorescent probes $\uparrow$
}

\author{
P. M. Pithan, D. Decker, S. I. Druzhinin, H. Ihmels, ${ }^{*}$ H. Schönherr and Y. Voß
}

Six new 8-styryl-substituted coralyne derivatives $4 a-f$ were synthesized from coralyne (2) by a base catalysed Knoevenagel type reaction. It was shown by photometric and fluorimetric titrations of double stranded and quadruplex DNA to $4 b-d$ as well as by fluorimetric DNA denaturation experiments that these ligands bind to DNA with different binding modes at varying ligand-DNA ratios (LDR). Specifically, the addition of DNA caused initially a hypochromic effect in absorbance and, at a particular LDR, the development of a new red shifted absorption band with a hyperchromic effect. Furthermore, $4 b-$ $\mathrm{d}$ induced a significant and selective stabilization of quadruplex DNA towards unfolding $\left(\Delta T_{\mathrm{m}}=31.6-\right.$ $32.9{ }^{\circ} \mathrm{C}$ at LDR $=5$ ), which is even more pronounced as compared to the parent compound coralyne (2). Most notably, the addition of DNA to the dimethylamino-substituted derivative $4 \mathrm{~b}$ leads to a new, strongly red-shifted emission band at $695 \mathrm{~nm}$. Hence, this derivative is a fluorescent probe that changes its fluorescence colour from green to red in the presence of DNA and even allows the fluorimetric analysis of living cells by staining of the nucleoli.

\section{Introduction}

The desire to develop efficient fluorescent probes for the detection of nucleic acids has gained great attention in chemistry, biology and medicine because emission spectroscopy is a highly sensitive method that requires only a relatively simple setup. ${ }^{1}$ Especially, there is an increasing interest for the selective detection of higher order DNA forms, e.g. G-quadruplex DNA structures (G4 DNA). ${ }^{2}$ Hence, a large number of so called "light-up" probes including (benz)imidazole, ${ }^{3}$ benzindole ${ }^{4}$ benzothiazole ${ }^{5}$ berberine,${ }^{6}$ coumarin, ${ }^{7}$ cyanine,${ }^{8}$ pyridinium, ${ }^{9}$ quinolinium, $^{\mathbf{1 0}}$ quinolizinium $^{\mathbf{1 1}}$ and thioflavine ${ }^{\mathbf{1 2}}$ based dyes have been developed whose emission quantum yield increases drastically upon binding to DNA.

Because of the proposed biological relevance of quadruplex DNA, ${ }^{13}$ numerous ligands have been investigated regarding their binding affinity and selectivity towards G4 DNA. ${ }^{\mathbf{1 4}}$ In order to achieve a high binding affinity, such a ligand should consist of an extended polycyclic (hetero)aromatic $\pi$ system, which allows sufficient overlap with the surface of the G-quartet. Moreover, it should have at least one positive charge in the core or in a side chain. ${ }^{15}$ Nevertheless, many ligands vary in topology and substitution pattern as the most prominent examples include porphyrines, acridines, anthraquinones, azoniahetarenes, cyanine

Department of Chemistry and Biology, University of Siegen, Center of Micro- and Nanochemistry and Engineering, Adolf-Reichwein-Str. 2, 57068 Siegen, Germany. E-mail: ihmels@chemie.uni-siegen.de

$\dagger$ Electronic supplementary information (ESI) available: Experimental procedures, additional spectroscopic data, ${ }^{1} \mathrm{H}$ and ${ }^{13} \mathrm{C}$ NMR spectra of 2 and $\mathbf{4 a - f}$. See DOI: 10.1039/c6ra27684a dyes and heteroaromatic natural products. ${ }^{16}$ G4 DNA was also targeted with heterocyclic alkaloids and their derivatives, such as palmatine, sanguarine, berberine (1) and coralyne (2). ${ }^{17}$ In this context, absorption and fluorescence studies with intramolecular anti-parallel G-quadruplex forming human telomeric TTAGGG repeat sequences revealed non-cooperative 1:1 binding for all the molecules, with 2 having a stronger binding affinity than the related alkaloids. ${ }^{18}$ Coralyne (2) also stabilizes G4 DNA more efficiently against thermal denaturation and it has a higher antitelomerase activity $\left(\mathrm{IC}_{50}=70 \mu \mathrm{M}\right)$ than berberine $(\mathbf{1}) \cdot{ }^{\mathbf{1 9}}$ Furthermore, it binds and stabilizes the anti-parallel G4 DNA structure formed by the insulin-linked polymorphic region (ILPR) $\left(K_{\mathrm{b}}{ }^{\mathbf{a} 2}=\right.$ $\left.2.5 \times 10^{6}\right) .{ }^{20}$ It also exhibits anti-leukemic activity ${ }^{21}$ as well as human topoisomerase I poisoning activity ${ }^{22}$ and it efficiently causes photoinduced DNA damage. ${ }^{23}$ It was found, too, that 2 forms strong inclusion complexes with cyclodextrins, which could be relevant for the development of drug delivery systems. ${ }^{24}$ Lastly, its high selectivity for triplex DNA in comparison to duplex DNA was established. ${ }^{25}$
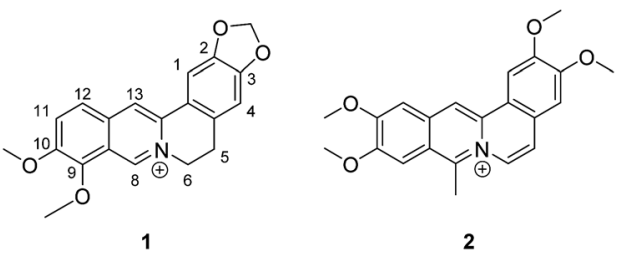

Along with its many positive attributes one drawback of coralyne (2) is that its interaction with DNA leads to fluorescence quenching. As quenching may also be induced by other external factors it is rather unspecific, so that the parent 
compound 2 can hardly be used for selective fluorimetric DNA detection. In this study we wanted to extend the $\pi$ system of the heterocyclic alkaloid coralyne (2) with a styryl substituent in order to functionalize it as a potential fluorescent probe and to achieve an increased affinity towards G4 DNA. We considered it an advantage that the DNA binding properties of 2 have already been investigated in detail (see above) ${ }^{26}$ and that styryl dyes have been established as useful probes in bioanalytical chemistry. In addition, synthesis of styryl dyes is straightforward and at the same time they generally exhibit a higher photostability than classical cyanine dyes. ${ }^{27}$ Moreover, styryl substituents were already introduced into several fluorescent ligands because they offer a flexible conjugated linkage. ${ }^{3 c, 9}$ Hence, we modified the 8position of coralyne (2) to obtain the 8-styryl-substituted derivatives $4 a-\mathbf{f}$ with different donor and acceptor substituents.

\section{Results}

\section{Synthesis}

Coralyne sulfoacetate (2SA) ${ }^{28}$ was converted to the tetrafluoroborate salt $\mathbf{2} \mathbf{B F}_{\mathbf{4}}$ by ion metathesis (Scheme 1). The latter was subsequently made to react with the aldehydes $3 \mathbf{a}-\mathbf{f}$ or their respective bis(1-piperidino)phenyl derivatives in a base catalysed Knoevenagel type reaction ${ }^{29}$ to give the 8-styryl-substituted coralyne derivatives 4a-f in $36-90 \%$ yield ( $c f$. ESI $\dagger$ ). The structures of the new compounds $\mathbf{4 a}-\mathbf{f}^{\mathbf{3 0}}$ were confirmed by NMR spectroscopic analysis $\left({ }^{1} \mathrm{H},{ }^{13} \mathrm{C}\right.$, COSY, HSQC, HMBC), massspectrometric data and elemental analysis. The anthrylsubstituted derivative $\mathbf{4 g}$ could not be obtained because $\mathbf{2} \mathbf{B F}_{4}$ decomposed under the reaction conditions. Presumably the steric hindrance of the peri-hydrogen atoms of the anthracene moiety suppresses the reaction. The $E$-configuration of the double bond in $4 \mathbf{a}-\mathbf{f}$ was established by the characteristic coupling constant of the vicinal alkene protons $\left({ }^{3} J=16-17 \mathrm{~Hz}\right)$.

\section{Photophysical properties}

Firstly, we investigated the photophysical properties of the coralyne derivatives $\mathbf{4 a}-\mathbf{f}$. The compounds $4 \mathbf{a}$ and $\mathbf{4 c - f}$ exhibit nearly the same spectroscopic properties with long wavelength absorption maxima at $\lambda_{\text {abs }}=434-438 \mathrm{~nm}$ and broad emission bands at $\lambda_{\mathrm{fl}}=475-484 \mathrm{~nm}$ in MeCN (Table 1, Fig. 1).

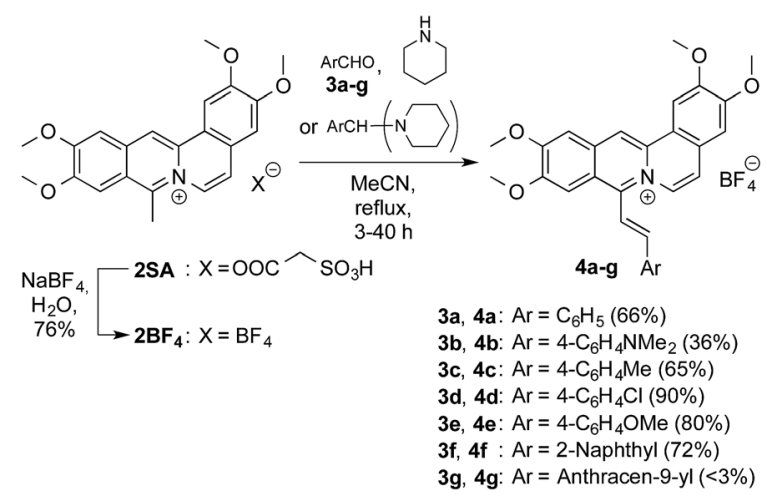

Scheme 1 Synthesis of the 8-styryl-substituted coralyne derivatives $4 a-f$.
Table 1 Absorption and emission properties of 2 and $4 a-f$ in $\mathrm{MeCN}$

\begin{tabular}{lllll}
\hline Derivative & $\lambda_{\text {abs }}{ }^{a} / \mathrm{nm}$ & $\lg \varepsilon^{b}$ & $\lambda_{\mathrm{fl}}{ }^{c} / \mathrm{nm}$ & $\Phi_{\mathrm{fl}}{ }^{d} / 10^{-2}$ \\
\hline $\mathbf{2}$ & 426 & 4.22 & 473 & 51 \\
4a & 434 & 4.22 & 475 & 4.1 \\
4b & 468 & 4.26 & 471 & 3.8 \\
4c & 436 & 4.25 & 484 & 0.8 \\
4d & 436 & 4.25 & 479 & 1.8 \\
4e & 438 & 4.27 & 479 & 1.9 \\
4f & 438 & 4.27 & 478 & 1.7
\end{tabular}

${ }^{a}$ Long-wavelength absorption maximum; $c=20 \mu \mathrm{M} .{ }^{b}$ Molar extinction coefficient. ${ }^{c}$ Fluorescence maximum (Abs. $=0.10$ at excitation wavelength $\lambda_{\mathrm{ex}}=400 \mathrm{~nm}$ ). ${ }^{d}$ Fluorescence quantum yield relative to coumarin $307\left(\Phi_{\mathrm{fl}}=0.58\right) ;{ }^{31}$ estimated error for fluorescence quantum yields: $\pm 10 \%$.

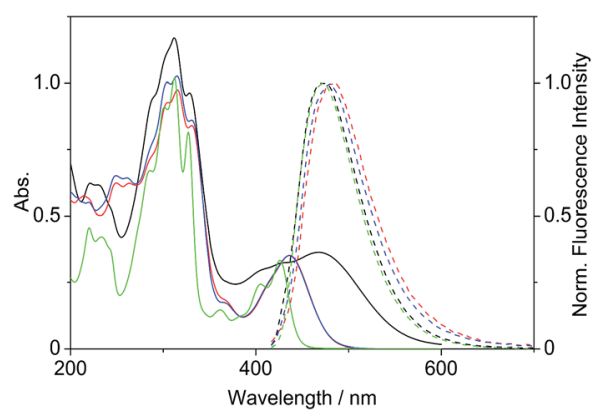

Fig. 1 Absorption ( $c=20 \mu \mathrm{M}$ in $\mathrm{MeCN}$, solid lines) and normalized emission spectra (Abs. $=0.10$ at $\lambda_{\mathrm{ex}}=400 \mathrm{~nm}$, dashed lines) of derivatives 2 (green), 4b (black), 4c (red) and 4d (blue).

The absorption maximum of the 4-dimethylaminostyrylsubstituted derivative $\mathbf{4 b}$, however, is red-shifted to $\lambda_{\mathrm{abs}}=$ $468 \mathrm{~nm}$, whereas its emission maximum remains in the same wavelength region than that of the derivatives $\mathbf{4 a}$ and $\mathbf{4 c}-\mathbf{f}\left(\lambda_{\mathrm{fl}}=\right.$ $471 \mathrm{~nm}$ ). Moreover, $\mathbf{4 b}$ exhibits dual fluorescence in glycerol with an additional red-shifted emission band at $\lambda_{\mathrm{fl}}=676 \mathrm{~nm}$, that is not present in MeCN or in aqueous buffer solution (Fig. 2 and $\mathrm{S} 2 \dagger)$. Remarkably, in glycerol both band intensities and their ratio $I_{676} / I_{479}$ decrease with increasing temperature from

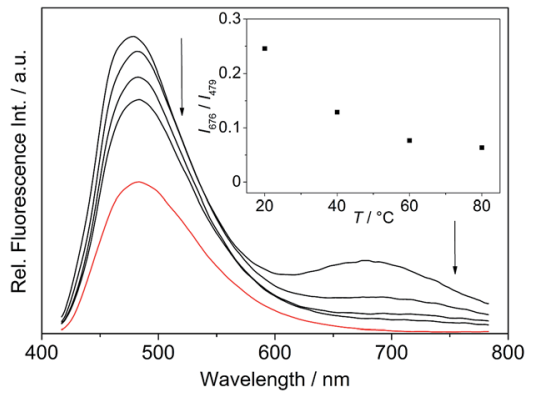

Fig. 2 Emission spectra of $4 \mathrm{~b}(c=2.5 \mu \mathrm{M}$, with $0.25 \% \mathrm{v} / \mathrm{v} \mathrm{DMSO})$ in glycerol (black lines) and in phosphate buffer $\left(\mathrm{C}_{\mathrm{Na}^{+}}=16 \mathrm{mM}, \mathrm{pH} 7.0\right)$ at $20{ }^{\circ} \mathrm{C}$ (red line); $\lambda_{\mathrm{ex}}=400 \mathrm{~nm}$. The arrows indicate the changes in emission intensity with increasing temperature. Inset: plot of the relative fluorescence intensity $I_{676} / I_{479}$ versus temperature. 

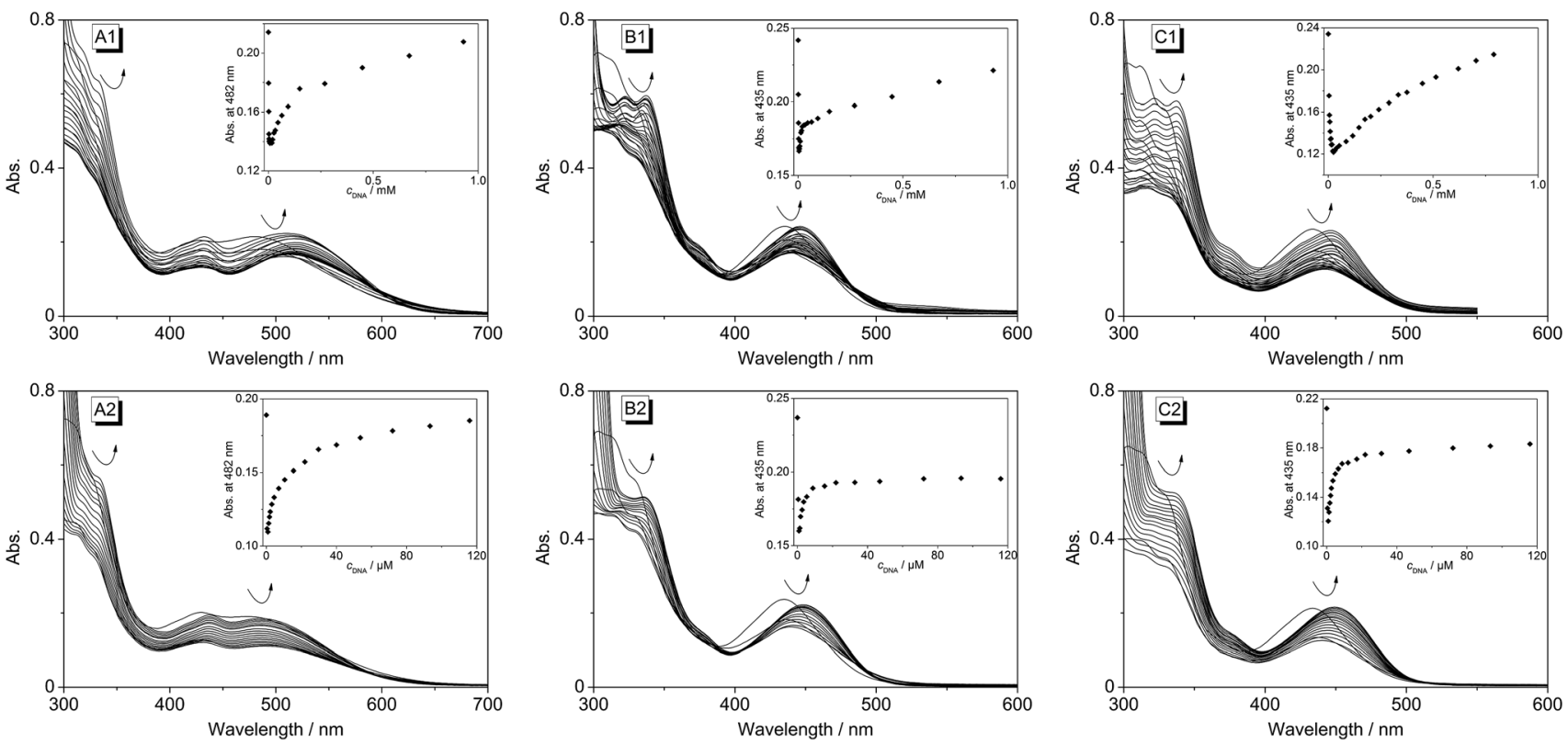

Fig. 3 Spectrophotometric titration of ct DNA (A1, B1, C1) and 22AG (A2, B2, C2) to the coralyne derivatives 4b (A), 4c (B), 4d (C) in phosphate $\operatorname{buffer}\left(c_{\mathrm{Na}^{+}}=16 \mathrm{mM}, \mathrm{pH} 7.0\right.$; with 10\% v/v DMSO) $c_{\mathrm{L}}=20 \mu \mathrm{M}, c_{\mathrm{ct}-\mathrm{DNA}, \mathrm{bp}}=1.34 \mathrm{mM}$ (A1 and B1), $c_{\mathrm{ct}-\mathrm{DNA}, \mathrm{bp}}=1.45 \mathrm{mM}(\mathrm{C} 1), c_{22 \mathrm{AG}}=360 \mu \mathrm{M}(\mathrm{A} 2$, $B 2, C 2)$. Insets: plot of absorption versus DNA concentration. The arrows indicate the changes of absorption upon addition of DNA.

$20{ }^{\circ} \mathrm{C}$ to $80{ }^{\circ} \mathrm{C}$ (inset in Fig. 2). In general, all derivatives $4 \mathbf{a}-\mathbf{f}$ are only weakly fluorescent $\left(\Phi_{\mathrm{fl}}<0.04 \mathrm{in} \mathrm{MeCN}\right)$ as compared to the parent compound coralyne $(2)\left(\Phi_{\mathrm{fl}}=0.51\right)$.

\section{DNA binding properties}

Spectrophotometric and spectrofluorimetric titrations. The changes of the absorbance upon addition of double-stranded ct DNA and the G4 DNA d[A(GGGTAA) ${ }_{3}$ GGG] (22AG) to the derivatives $\mathbf{4 b}-\mathbf{d}$ were followed by spectrophotometric titrations. At the beginning of each titration the absorbance decreased until a particular ligand-to-DNA ratio (LDR) was reached (Fig. 3). This hypsochromic effect occurred for $\mathbf{4 b}-\mathbf{d}$ at the same LDR $(>22)$ upon addition of 22AG, but at different LDRs upon addition of ct DNA (4b: LDR > 2.7, 4c: LDR > 4.8, 4d: LDR > 1.4). Subsequently, the absorption increased at lower LDR, and a red shift of the absorption maximum was observed. In the case of ligands 4c and 4d, the red shift is slightly more pronounced upon addition of 22AG $(\Delta \lambda=14 \mathrm{~nm})$ as compared to addition of ct
DNA $(\Delta \lambda=11 \mathrm{~nm})$. The largest red shift was observed when ct DNA was added to $\mathbf{4 b}(\Delta \lambda=28 \mathrm{~nm})$, whereas no red shift occurred in the presence of 22AG (Table 2). In general, isosbestic points could not be detected during the titrations.

Upon excitation at $\lambda_{\mathrm{ex}}=400 \mathrm{~nm}$ the derivatives $4 \mathbf{b}-\mathbf{d}$ exhibit broad emission bands at $480 \mathrm{~nm}(\mathbf{4 b}), 492 \mathrm{~nm}(4 \mathbf{c})$ and $486 \mathrm{~nm}$ (4d) in aqueous buffer solution (Fig. 4 and $\mathrm{S} 1 \dagger$ ). The addition of ct DNA and 22AG to $\mathbf{4 b}$ led to a continuous decrease of the fluorescence intensity with increasing DNA concentration at the emission maximum $\left(\lambda_{\mathrm{fl}}=480 \mathrm{~nm}\right)$, and also to the development of a new emission band at $695 \mathrm{~nm}$. Since the ligand is not fluorescent between 600 and $850 \mathrm{~nm}$ in the absence of DNA, the spectra were also recorded at an excitation wavelength of $\lambda_{\mathrm{ex}}=$ $500 \mathrm{~nm}$ in order to achieve a better light-up effect. The increase in fluorescence intensity of the red-shifted emission band is more pronounced upon addition of ct DNA $\left(I / I_{0}=125\right)$ as compared to addition of 22AG $\left(I / I_{0}=53\right)$. The binding isotherms were analysed according to an established protocol ${ }^{32}$ assuming a non-competitive binding mode (insets in Fig. 4A2

Table 2 Absorption and emission properties of 2 and $4 b-d$ in the presence of ct DNA and $22 A G$

\begin{tabular}{|c|c|c|c|c|c|c|c|c|c|}
\hline Derivative & $\lambda_{\mathrm{abs}}{ }^{a} / \mathrm{nm}$ & $\lg \varepsilon^{b}$ & $\Delta \lambda_{\text {abs,ct-DNA }}{ }^{c} / \mathrm{nm}$ & $\Delta \lambda_{\mathrm{abs}, \mathbf{2 2 A G}}{ }^{c} / \mathrm{nm}$ & $\lambda_{\mathrm{fl}}{ }^{d} / \mathrm{nm}$ & $\Delta \lambda_{\mathrm{fl}, \mathrm{ct}-\mathrm{DNA}}{ }^{e} / \mathrm{nm}$ & $\Delta \lambda_{\mathrm{fl}, \mathbf{2 2 A G}}{ }^{e} / \mathrm{nm}$ & $K_{\mathrm{ct}-\mathrm{DNA}}{ }^{f} / 10^{5} \mathrm{M}^{-1}$ & $K_{22 \mathrm{AG}}^{f} / 10^{5} \mathrm{M}^{-1}$ \\
\hline 2 & $421^{g}$ & $4.16^{g}$ & $-^{h}$ & $3^{g}$ & $472^{g}$ & $-^{h}$ & $-^{h}$ & $7.0^{i}$ & $50^{g}$ \\
\hline $4 b$ & 482 & 4.03 & 28 & 0 & 480 & 215 & 215 & 2.3 & 0.33 \\
\hline 4d & 435 & 4.07 & 11 & 14 & 486 & 13 & 13 & $-^{h}$ & $-^{h}$ \\
\hline
\end{tabular}

${ }^{a}$ Long-wavelength absorption maximum; $c=20 \mu \mathrm{M}$ in phosphate buffer $\left(c_{\mathrm{Na}^{+}}=16 \mathrm{mM}\right.$, pH 7.0; with $10 \% \mathrm{v} / \mathrm{v}$ DMSO). ${ }^{b}$ Molar extinction coefficient. ${ }^{c}$ Shift of the long-wavelength absorption maximum between free and bound ligand. ${ }^{d}$ Long-wavelength emission maximum; $c=20 \mu \mathrm{M}$ in phosphate buffer $\left(c_{\mathrm{Na}^{+}}=16 \mathrm{mM}, \mathrm{pH} 7.0\right.$; with $10 \% \mathrm{v} / \mathrm{v}$ DMSO$) ; \lambda_{\mathrm{ex}}=400 \mathrm{~nm}$. ${ }^{e}$ Shift of the long-wavelength emission maximum between free and bound ligand. ${ }^{f}$ Binding constant $K$ determined from fluorimetric titrations. ${ }^{g}$ Ref. $26 .{ }^{h}$ Not determined. ${ }^{i}$ Ref. 18. 

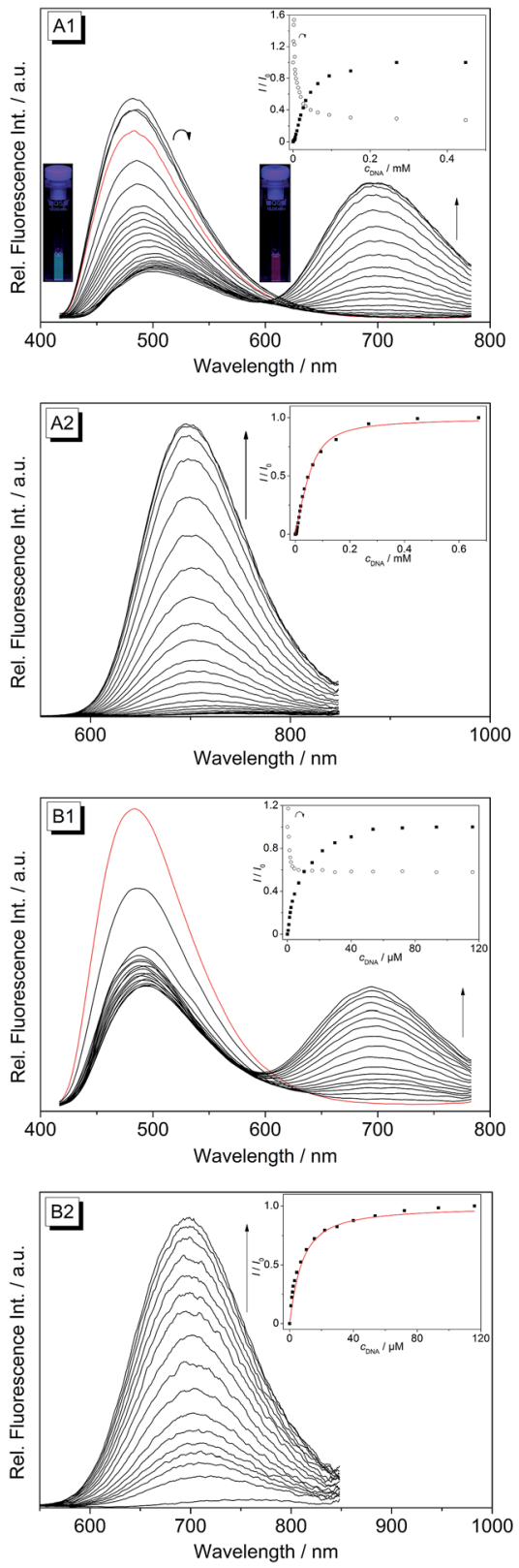

Fig. 4 Spectrofluorimetric titration of ct DNA (A1 and A2) and 22AG (B1 and B2) to the coralyne derivative $4 \mathrm{~b}$ in phosphate buffer $\left(\mathrm{CNa}_{\mathrm{Na}^{+}}=\right.$ $16 \mathrm{mM}, \mathrm{pH} 7.0$; with $10 \% \mathrm{v} / \mathrm{v}$ DMSO) $\left[c_{\mathrm{L}}=20 \mu \mathrm{M}, c_{\mathrm{ct}-\mathrm{DNA}, \mathrm{bp}}=1.34 \mathrm{mM}\right.$, $c_{22 \mathrm{AG}}=360 \mu \mathrm{M}, \lambda_{\mathrm{ex}}=400 \mathrm{~nm}(\mathrm{~A} 1$ and $\mathrm{B} 1)$ and $500 \mathrm{~nm}$ (A2 and B2)]. Insets: plot of the relative fluorescence intensity $/ / I_{0}$ (corrected with regard to the change of the absorption at the excitation wavelength) versus DNA concentration at $\lambda_{\mathrm{fl}}=480 \mathrm{~nm}(\mathrm{O})$ and $695 \mathrm{~nm}$ ( $\boldsymbol{\square}$ ). The emission spectra of the pure ligand solution are depicted in red. The arrows indicate the changes in emission intensity upon addition of DNA. The inset pictures in (A1) show the fluorescence colours of $4 \mathrm{~b}$ in the absence and in the presence of ct DNA; $\lambda_{\text {ex }}=366 \mathrm{~nm}$. The contrast and brightness were enhanced by $30 \%$ without changing the true colours.

and $\mathrm{B} 2$, red lines) to obtain the binding constants for $\mathbf{4 b}$ $\left(K_{\text {ct-DNA }}=2.3 \times 10^{5} \mathrm{M}^{-1}, K_{22 \mathrm{AG}}=3.3 \times 10^{4} \mathrm{M}^{-1}\right)$. Unfortunately, the results of the fluorimetric titrations of DNA to $4 \mathbf{c}$ and $4 \mathbf{d}$ did not allow the determination of the respective binding constants because in each case the fluorescence intensity was only marginally affected by addition of DNA $\left(0.6<I / I_{0}<2.0\right)$ and only resulted in fluctuating emission intensities (Fig. S1 $\dagger$ ). However, with increasing DNA concentration the emission bands were red-shifted by $9-15 \mathrm{~nm}$.

\section{Thermal denaturation experiments}

The binding properties of ligands $\mathbf{4 b}$-d and of coralyne (2), for direct comparison, with G4 DNA were further investigated by thermal denaturation experiments. For that purpose, the changes of the melting temperature of the quadruplex-forming oligonucleotide F21T [fluo-GGG(TTAGGG) ${ }_{3}$-tamra], that is endlabeled with two fluorophores, were determined in the presence of the ligands at different LDR according to an established protocol. ${ }^{33}$ The melting temperature of F21T, that denotes 50\% disassembly of the quadruplex to the unfolded single-strand, was $T_{\mathrm{m}}=44.3 \pm 0.5{ }^{\circ} \mathrm{C}$ and was not affected by the presence of $1 \%$ DMSO. The latter was added in the denaturation experiments in order to ensure the solubility of $\mathbf{4 b}-\mathbf{d}$ in aqueous buffer solution. The oligonucleotide F21T is highly stabilized towards unfolding by all of the tested ligands (Table 3). The highest stabilization of F21T is achieved in the presence of $\mathbf{4 d}$ $\left(\Delta T_{\mathrm{m}}=32.9^{\circ} \mathrm{C}\right.$ at $\left.\mathrm{LDR}=5\right)$, while the parent compound, 2 , has a smaller effect on the melting temperature at the same LDR $\left(\Delta T_{\mathrm{m}}=27.0^{\circ} \mathrm{C}\right)$. In the presence of a 15 -fold excess of the selfcomplementary duplex forming oligonucleotide ds26 the induced shifts of the melting temperature are only marginally affected $\left(\Delta \Delta T_{\mathrm{m}}=0.5-2.4{ }^{\circ} \mathrm{C}\right)$. Remarkably, all the melting curves show two transitions in the presence of 2 and $\mathbf{4 b}-\mathbf{d}$ at $\mathrm{LDR}=1.3$ (Fig. $\mathrm{S} 3 \dagger$ ), which resulted in a bimodal shape of their first derivative (Fig. S4 $\dagger$ ). Therefore, the melting temperatures at this LDR could not be determined unambiguously.

\section{Fluorimetric analysis of cells}

Because of the ability of $\mathbf{4 b}$ to indicate the presence of DNA by the change of emission colour (Fig. 4), it was also investigated whether $\mathbf{4 b}$ is capable to enter living cells and to visualize

Table 3 Shift of melting temperature, $\Delta T_{m}$, of quadruplex DNA F21T in the presence of the ligands 2 and $4 b-d$ at different LDR without and with the duplex DNA ds26 as determined by fluorimetric thermal denaturation studies

\begin{tabular}{|c|c|c|c|c|}
\hline \multirow[b]{3}{*}{ Ligand } & \multicolumn{4}{|c|}{$\Delta T_{\mathrm{m}} /{ }^{\circ} \mathrm{C}$ at different $\mathrm{LDR}^{a}$} \\
\hline & \multicolumn{2}{|c|}{ Without ds26 } & \multicolumn{2}{|c|}{ With ds26 ${ }^{b}$} \\
\hline & 2.5 & 5.0 & 2.5 & 5.0 \\
\hline $2 \mathrm{BF}_{4}$ & 21.7 & 27.0 & 20.0 & 26.5 \\
\hline $4 b$ & 28.2 & 31.6 & 21.3 & 30.7 \\
\hline $4 \mathrm{c}$ & 25.9 & 31.8 & 23.3 & 29.4 \\
\hline 4d & 28.1 & 32.9 & 25.5 & 31.4 \\
\hline
\end{tabular}

${ }^{a} \Delta T_{\mathrm{m}}$ of F21T; $c_{\mathbf{F 2 1 T}}=0.2 \mu \mathrm{M}$ (in oligonucleotide); KCl-LiCl-Nacacodylate buffer $\left(10 \mathrm{mM} \mathrm{K}^{+}, 10 \mathrm{mM} \mathrm{Na}^{+}, 90 \mathrm{mM} \mathrm{Li}^{+}, \mathrm{pH} 7.2\right) ; \lambda_{\mathrm{ex}}=$ $470 \mathrm{~nm} ; \lambda_{\mathrm{em}}=515 \mathrm{~nm}$; estimated error: $\pm 0.5{ }^{\circ} \mathrm{C}$ of the given data. ${ }^{b} c_{\mathrm{ds26}}=3.0 \mu \mathrm{M}$. 

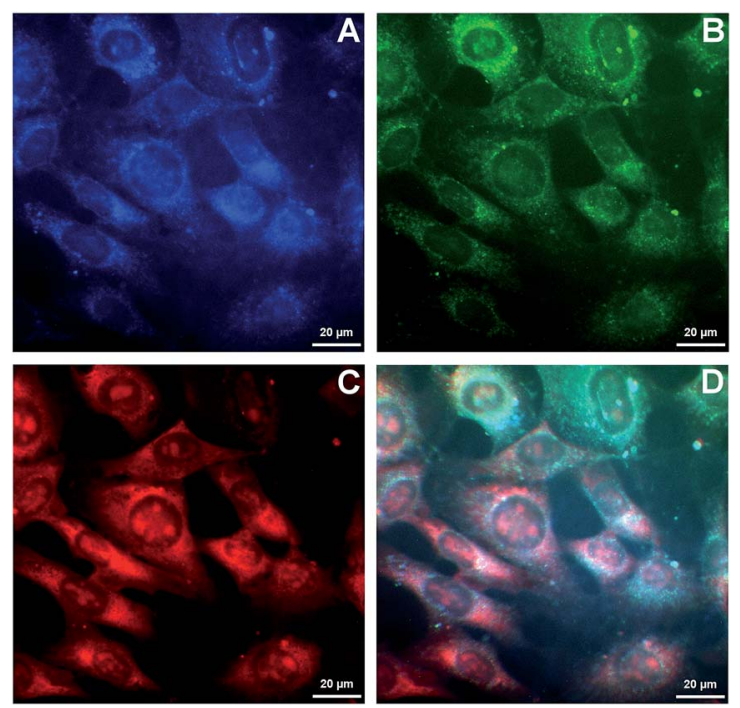

Fig. 5 Epifluorescence microscopy images of NIH 3 T3 mouse fibroblasts after incubation with $4 \mathrm{~b}(2.5 \mu \mathrm{M})$ for $1 \mathrm{~h}$. Pictures were taken with an Axiovert 135 microscope (AxioCam MRm). The different emission colours were separated by blocking filters. Panel (A): $\lambda_{\text {ex }}=320-$ $390 \mathrm{~nm}, \lambda_{\mathrm{em}}=415-470 \mathrm{~nm}$; panel (B): $\lambda_{\mathrm{ex}}=450-490 \mathrm{~nm}, \lambda_{\mathrm{em}}>$ $515 \mathrm{~nm}$; panel (C): $\lambda_{\mathrm{ex}}=535-560 \mathrm{~nm}, \lambda_{\mathrm{em}}>585 \mathrm{~nm}$; panel (D): overlay of all pictures.

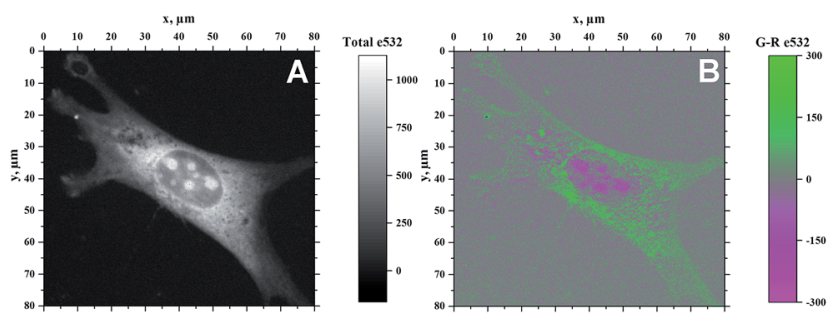

Fig. 6 Confocal fluorescence microscopy images of NIH 3 T3 mouse fibroblasts after incubation with $4 \mathrm{~b}(2.5 \mu \mathrm{M})$ for $1 \mathrm{~h}\left(\lambda_{\mathrm{ex}}=532 \mathrm{~nm}\right)$. Pictures were taken with a Microtime 200 confocal fluorescence microscope system (PicoQuant). Panel (A): without filter; panel (B): different emission colours separated by blocking filters (green channel: $\lambda_{\mathrm{em}}>515 \mathrm{~nm}$, red channel: $\lambda_{\mathrm{em}}=652-732 \mathrm{~nm}$ ).

distinct cell components. Therefore, NIH 3T3 mouse fibroblasts were treated with $4 \mathbf{b}(2.5 \mu \mathrm{M})$ and analysed by epifluorescence microscopy after $1 \mathrm{~h}$ of incubation (Fig. 5). By means of different cut-off filters a multi-colour picture was obtained that did not change with longer incubation times. Remarkably, the nucleoli showed only a red emission, whereas additional blue and green emission areas were detected in the cytoplasm. In order to visualize the distinct cell components in more detail, additional confocal fluorescence microscopy images of single cells were obtained (Fig. 6). It can be clearly recognized that the red emission is much more pronounced in the nucleoli (Fig. 6B).

\section{Discussion}

The derivatives $\mathbf{4 b}-\mathbf{d}$ were investigated with regard to their DNA binding properties. Firstly, the course of all spectrophotometric titrations, i.e. the absence of an isosbestic point, clearly reveals that $\mathbf{4 b}-\mathbf{d}$ bind to DNA with different binding modes at varying LDR. Because of the complex binding situation, the respective binding isotherms could not be fitted to a theoretical model. The derivatives $\mathbf{4} \mathbf{c}$ and $\mathbf{4 d}$ show similar DNA binding properties with almost identical bathochromic shifts of the absorption and emission bands (Table 2). This behaviour is in agreement with the observation that a chloro substituent affects the DNA binding properties of a ligand in a similar manner as a methyl substituent. ${ }^{34}$ The results of the spectrometric titrations of DNA to $\mathbf{4 b}$ indicate, on the one side, a preferred binding to duplex DNA over G4 DNA because a significant bathochromic shift of the absorbance maximum was only detected in the presence of ct DNA (Fig. 3A1 and A2). Moreover, the respective binding constant obtained from fluorimetric titrations is approximately one order of magnitude higher for ct DNA (Table 2).

On the other side, the induced shifts of melting temperature of the G4 DNA forming oligonucleotide F21T in presence of 2 and 4b-d revealed a significant and highly selective stabilization of G4 DNA. While the melting temperature of F21T in the presence of the parent compound $\mathbf{2}$ is in good agreement with literature data $\left(\Delta T_{\mathrm{m}}=27.0^{\circ} \mathrm{C}\right.$ at $\left.\mathrm{LDR}=5\right),{ }^{19}$ the extension of the conjugated aromatic $\pi$ system of 2 indeed further enhances the stabilizing effect on G4 DNA by $4.6-5.9{ }^{\circ} \mathrm{C}$, thus indicating that the styryl substituent causes an increased affinity of the ligand. Remarkably, the presence of an excess of duplex DNA has only a small effect on the induced shifts of melting temperature (Fig. 7, Table S2 $\dagger$ ), which indicates that all of the tested ligands selectively stabilize G4 DNA over duplex DNA. It should be noted that the latter result seems to be inconsistent with the determined binding constants (Table 2) that revealed a higher affinity of the ligand $\mathbf{4 b}$ to duplex DNA than to quadruplex DNA. The reason for this inconsistency most likely lies in the different ionic strength and composition of the buffer solutions that were employed in the different experiments. Due to the limited solubility of the ligands in aqueous solution at high ionic strength, the titrations used for the determination of the $K_{\mathrm{b}}$ values were performed in $16 \mathrm{mM}$ sodium phosphate buffer, in which the antiparallel quadruplex form of 22AG is the predominant species. ${ }^{35}$ In contrast, the DNA denaturation experiments were performed in $\mathrm{K}^{+}$-containing cacodylate buffer at significantly higher ionic strength. In the latter medium, the telomeric oligonucleotide sequence folds into different quadruplex structures, namely in two intramolecular $(3+1) \mathrm{G}-$
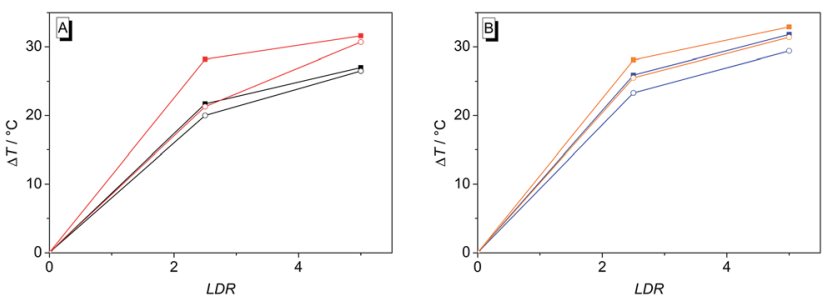

Fig. 7 Induced shift of the melting temperature, $\Delta T_{m}$, of G4 DNA F21T $(0.2 \mu \mathrm{M})$ upon addition of ligands 2 ( $\mathrm{A}$, black lines), $4 \mathrm{~b}$ ( $\mathrm{A}, \mathrm{red}), 4 \mathrm{c}$ (B, blue) and $4 d(B$, orange) in the absence $(\boldsymbol{D})$ and in the presence $(O)$ of duplex DNA ds26 (3 $\mu \mathrm{M})$ in aq. $\mathrm{KCl}-\mathrm{LiCl}-\mathrm{Na}$-cacodylate buffer $(10 \mathrm{mM}$ $\left.\mathrm{K}^{+}, 10 \mathrm{mM} \mathrm{Na}+90 \mathrm{mM} \mathrm{Li}{ }^{+}, \mathrm{pH} 7.2\right)$ at different $\operatorname{LDR}(0,2.5,5)$. 
quadruplexes, and a basket-type G-quadruplex with only two neighbouring G-tetrads. ${ }^{36}$ Moreover, we expect that the binding constants of the ligands with ct DNA are most likely much smaller in potassium buffer at higher ionic strength. ${ }^{37}$

The occurrence of two distinct transitions in all of the melting curves at LDR $=1.3$ (Fig. S3 $\dagger$ ) cannot be explained unequivocally. This effect was briefly discussed in the literature already, but in that case an accurate explanation was not given. ${ }^{33}$ It appears, however, that the first transition corresponds to the melting of the unstabilized F21T in absence of a ligand $\left(T_{\mathrm{m}} \approx 46{ }^{\circ} \mathrm{C}\right)$ and the second one to the highly stabilized ligand-DNA complex $\left(T_{\mathrm{m}} \approx 72^{\circ} \mathrm{C}\right)$ (Fig. S4 $\dagger$ ).

The change in emission colour and the corresponding lightup effect of $\mathbf{4 b}$ at $\lambda_{\mathrm{fl}}=695 \mathrm{~nm}$ in the presence of DNA can already be recognized by the naked eye under UV light (Fig. 4A). The emission shift is likely the result of suppressed deactivation pathways in the excited state, namely torsional relaxation, because of the reduced conformational flexibility within the binding site. ${ }^{38}$ In particular, this effect was observed for quinolizinium derivatives, ${ }^{39}$ namely the 9-(4-dimethylaminophenyl)benzo $[b]$ quinolizinium in the presence of ct DNA or 22AG, ${ }^{11}$ and berberine and sanguarine in the presence of abasic site-containing DNA. ${ }^{40}$ This explanation is consistent with the observation that the red-shifted emission band of $\mathbf{4 b}$ is also present in a highly viscous solvent such as glycerol, in which the conformational flexibility is reduced leading to two distinct emitting species (Fig. 2).

As the green emission of $\mathbf{4 b}$ at $\lambda_{\mathrm{fl}}=471 \mathrm{~nm}$ in MeCN or $480 \mathrm{~nm}$ in aq. buffer solution is essentially the same as the one observed for coralyne (2), it obviously originates from the azoniatetraphene fluorophore that is not affected by the aminostyryl substituent. At the same time, the absorption spectrum of $\mathbf{4 b}$ is significantly red shifted as compared to the parent compound $\mathbf{2}$, which clearly indicates a donor-acceptor interplay between the aminophenyl group and the quinolizinium unit in the ground state, whose direct excitation should result in a locally excited (LE) state with a pronounced charge shift (CS) character and a corresponding red-shifted emission (Scheme 2). The latter, however, is only observed in glycerol $\left(\lambda_{F}=676 \mathrm{~nm}\right)$ or when the compound is bound to DNA $\left(\lambda_{\mathrm{F}}=695 \mathrm{~nm}\right)$. These observations point to a fast relaxation of the initially formed CS state in solution to give a twisted conformation, presumably to release steric strain, that decouples the aminostyryl unit from

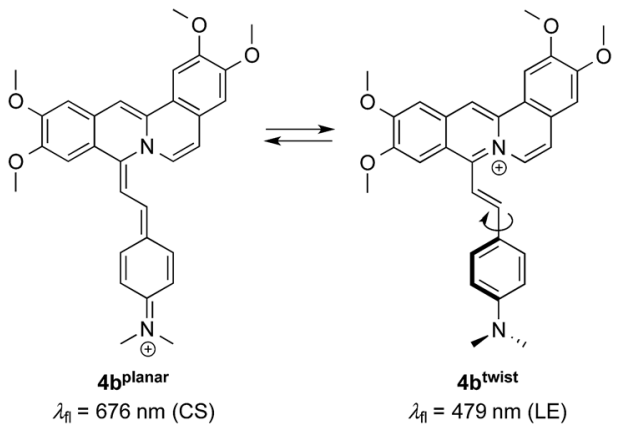

Scheme 2 Different emitting conformers of $4 b$ in glycerol. the fluorophore resulting in a blue-shifted coralyne-type emission. In media with restricted free volume, i.e. glycerol or DNA, the torsional relaxation is slower than the emission from the locally excited CS state, so that under these conditions the red shifted emission is observed. In turn, the relative emission intensity $I_{676} / I_{479}$ between the two emission bands decreases with increasing temperature and therefore decreasing viscosity, thus, indicating that the CS band is sensitive to the medium and not observable in a non-viscous solution. In this regard, it was tempting to test, whether $\mathbf{4 b}$ also allows the fluorimetric differentiation of distinct cell components. Indeed, the fluorimetric analysis of living cells that were stained with $\mathbf{4 b}$ not only revealed its ability to permeate into the cells, but also to stain distinct cell components, i.e. the nucleoli, which were mainly visible in the red emission channel (Fig. 5 and 6). Since the emission colour of $\mathbf{4 b}$ depends on its environment as well as on the used excitation wavelength (see above), the red emission in the nuclei could therefore be indicative of DNA-bound ligands.

\section{Conclusions}

The base-catalysed Knoevenagel type reaction of methylsubstituted quinolizinum derivatives was successfully employed to transform coralyne (2) into six new 8-styryl-substituted coralyne derivatives. As revealed by spectrometric titrations and thermal denaturation experiments, the derivatives $\mathbf{4 b}-\mathbf{d}$ exhibit significant binding interactions to DNA. Especially, they cause an even more pronounced stabilization of G4 DNA in comparison to coralyne (2). Most notably, the 8-(4'-dimethylamino)styrylsubstituted derivative $\mathbf{4 b}$ is a fluorescent probe that not only features a fluorescence light-up effect at $695 \mathrm{~nm}$, but also changes its fluorescence colour from green to red in the presence of DNA. Unfortunately, a differentiation between duplex and quadruplex DNA was not achieved; however, the derivative $\mathbf{4 b}$ enables the fluorimetric analysis of living cells.

\section{Acknowledgements}

This paper is dedicated to Prof. Dr Adalbert Maercker on the occasion of his 85th birthday. Financial support by the Deutsche Forschungsgemeinschaft (INST 221/87-1 FUGG), the European Research Council (ERC grant to HS, ERC grant agreement No. 279202), and the University of Siegen is gratefully acknowledged. NIH 3T3 mouse fibroblasts were kindly provided by Dr Jürgen Schnekenburger (Biomedical Technology Center of the Medical Faculty Münster, Germany). PMP thanks the Fond der Chemischen Industrie for a PhD fellowship.

\section{Notes and references}

1 (a) D.-L. Ma, H.-Z. He, K.-H. Leung, H.-J. Zhong, D. S.-H. Chan and C.-H. Leung, Chem. Soc. Rev., 2013, 42, 3427-3440; (b) H. Kobayashi, M. Ogawa, R. Alford, P. L. Choyke and Y. Urano, Chem. Rev., 2010, 110, 26202640; (c) D. M. Kolpashchikov, Chem. Rev., 2010, 110, 47094723; (d) R. W. Sinkeldam, N. J. Greco and Y. Tor, Chem. 
Rev., 2010, 110, 2579-2619; (e) A. Granzhan, H. Ihmels and M. Tian, ARKIVOC, 2015, vi, 494-523.

2 (a) B. R. Vummidi, J. Alzeer and N. W. Luedtke, ChemBioChem, 2013, 14, 540-558; (b) E. Largy, A. Granzhan, F. Hamon, D. Verga and M.-P. TeuladeFichou, Top. Curr. Chem., 2013, 330, 111-177.

3 (a) B. Jin, X. Zhang, W. Zheng, X. Liu, C. Qi, F. Wang and D. Shangguan, Anal. Chem., 2014, 86, 943-952; (b) Y. Wei, X. Zhang, L. Wang, Y. Liu, T. Bing, X. Liu and D. Shangguan, RSC Adv., 2015, 5, 75911-75917; (c) S. Wu, L. Wang, N. Zhang, Y. Liu, W. Zheng, A. Chang, F. Wang, S. Li and D. Shangguan, Chem.-Eur. J., 2016, 22, 60376047; (d) S.-B. Chen, W.-B. Wu, M.-H. Hu, T.-M. Ou, L.-Q. Gu, J.-H. Tan and Z.-S. Huang, Chem. Commun., 2014, 50, 12173-12176; (e) M.-H. Hu, S.-B. Chen, R.-J. Guo, T.-M. Ou, Z.-S. Huang and J.-H. Tan, Analyst, 2015, 140, 4616-4625.

4 D. Lin, X. Fei, Y. Gu, C. Wang, Y. Tang, R. Li and J. Zhou, Analyst, 2015, 140, 5772-5780.

5 Y.-J. Lu, S.-C. Yan, F.-Y. Chan, L. Zou, W.-H. Chung, W.-L. Wong, B. Qiu, N. Sun, P.-H. Chan, Z.-S. Huang, L.-Q. Gu and K.-Y. Wong, Chem. Commun., 2011, 47, 49714973.

6 (a) L. Xu, S. Hong, N. Sun, K. Wang, L. Zhou, L. Ji and R. Pei, Chem. Commun., 2016, 52, 179-182; (b) C.-Q. Zhou, J.-W. Yang, C. Dong, Y.-M. Wang, B. Sun, J.-X. Chen, Y.-S. Xu and W.-H. Chen, Org. Biomol. Chem., 2016, 14, 191-197.

7 (a) J.-w. Yan, Y.-g. Tian, J.-H. Tan and Z.-S. Huang, Analyst, 2015, 140, 7146-7149; (b) M. Zuffo, F. Doria, V. Spalluto, S. Ladame and M. Freccero, Chem.-Eur. J., 2015, 21, 1759617600.

8 (a) X. Chen, J. Wang, G. Jiang, G. Zu, M. Liu, L. Zhou and R. Pei, RSC Adv., 2016, 6, 70117-70123; (b) H. Ihmels and L. Thomas, Org. Biomol. Chem., 2013, 11, 480-487; (c) B. Karg, A. Funke, A. Ficht, A. Sievers-Engler, M. Lämmerhofer and K. Weisz, Chem.-Eur. J., 2015, 21, 13802-13811.

9 X. Xie, B. Choi, E. Largy, R. Guillot, A. Granzhan and M.-P. Teulade-Fichou, Chem.-Eur. J., 2013, 19, 1214-1226.

10 P. Yang, A. De Cian, M.-P. Teulade-Fichou, J.-L. Mergny and D. Monchaud, Angew. Chem., Int. Ed., 2009, 48, 2188-2191.

11 R. Bortolozzi, H. Ihmels, L. Thomas, M. Tian and G. Viola, Chem.-Eur. J., 2013, 19, 8736-8741.

12 (a) V. Gabelica, R. Maeda, T. Fujimoto, H. Yaku, T. Murashima, N. Sugimoto and D. Miyoshi, Biochemistry, 2013, 52, 5620-5628; (b) A. La Renaud de Faverie, A. Guedin, A. Bedrat, L. A. Yatsunyk and J.-L. Mergny, Nucleic Acids Res., 2014, 42, e65.

13 S. Neidle, J. Med. Chem., 2016, 59, 5987-6011.

14 (a) Y. Xu, Chem. Soc. Rev., 2011, 40, 2719-2740; (b) A. Ali and S. Bhattacharya, Bioorg. Med. Chem., 2014, 22, 4506-4521.

15 P. Murat, Y. Singh and E. Defrancq, Chem. Soc. Rev., 2011, 40, 5293-5307.

16 (a) J. L.-Y. Chen, J. Sperry, N. Y. Ip and M. A. Brimble, MedChemComm, 2011, 2, 229; (b) A. Granzhan and H. Ihmels, Synlett, 2016, 27, 1775-1793; (c) S. A. Ohnmacht and S. Neidle, Bioorg. Med. Chem. Lett., 2014, 24, 26022612; (d) B. Maji and S. Bhattacharya, Chem. Commun., 2014, 50, 6422-6438.

17 Y.-X. Xiong, Z.-S. Huang and J.-H. Tan, Eur. J. Med. Chem., 2015, 97, 538-551.

18 K. Bhadra and G. S. Kumar, Med. Res. Rev., 2011, 31, 821862.

19 M. Franceschin, L. Rossetti, A. D'Ambrosio, S. Schirripa, A. Bianco, G. Ortaggi, M. Savino, C. Schultes and S. Neidle, Bioorg. Med. Chem. Lett., 2006, 16, 1707-1711.

20 D. Dzubiel, H. Ihmels, M. M. A. Mahmoud and L. Thomas, Beilstein J. Org. Chem., 2014, 10, 2963-2974.

21 (a) K. Y. Zee-Cheng and C. C. Cheng, J. Pharm. Sci., 1973, 62, 1572-1573; (b) M. Sanders, A. Liu, T.-K. Li, H.-Y. Wu, S. Desai, Y. Mao, E. Rubin, E. LaVoie, D. Makhey and L. Liu, Biochem. Pharmacol., 1998, 56, 1157-1166.

22 (a) D. Makhey, B. Gatto, C. Yu, A. Liu, L. F. Liu and E. J. LaVoie, Bioorg. Med. Chem., 1996, 4, 781-791; (b) B. S. Patro, B. Maity and S. Chattopadhyay, Antioxid. Redox Signaling, 2010, 12, 945-960.

23 H. Ihmels and A. Salbach, Photochem. Photobiol., 2006, 82, 1572-1576.

24 S. Hazra, M. Hossain and G. S. Kumar, J. Inclusion Phenom. Macrocyclic Chem., 2014, 78, 311-323.

25 (a) L. J. P. Latimer, N. Payton, G. Forsyth and J. S. Lee, Biochem. Cell Biol., 1995, 73, 11-18; (b) J. S. Lee, L. J. P. Latimer and K. J. Hampel, Biochemistry, 1993, 32, 5591-5597; (c) J. Ren and J. B. Chaires, Biochemistry, 1999, 38, 16067-16075; (d) F. Xing, G. Song, J. Ren, J. B. Chaires and X. Qu, FEBS Lett., 2005, 579, 5035-5039.

26 K. Bhadra and G. S. Kumar, Biochim. Biophys. Acta, 2011, 1810, 485-496.

27 T. Deligeorgiev, A. Vasilev, S. Kaloyanova and J. J. Vaquero, Color. Technol., 2010, 126, 55-80.

28 K. Y. Zee-Cheng and C. C. Cheng, J. Pharm. Sci., 1972, 61, 969-971.

29 (a) K. Sato, K. Nakajima, S. Arai and T. Yamagishi, Liebigs Ann., 1996, 439-446; (b) S. Arai, K. Sato, K. Kano, T. Yafune, M. Hida and T. Yamagishi, Heterocycles, 1994, 37, 955-965.

30 The derivatives 4a (CAS 1037305-51-3) and 4d (CAS 103730564-8) are registered compounds in the SciFinder ${ }^{\circledR}$ with no given references.

31 (a) G. Jones, W. R. Jackson, C. Y. Choi and W. R. Bergmark, J. Phys. Chem., 1985, 89, 294-300; (b) G. A. Crosby and J. N. Demas, J. Phys. Chem., 1971, 75, 991-1024; (c) B. Valeur and M. N. Berberan-Santos, Molecular fluorescence. Principles and applications, WileyVCH, Weinheim, 2nd edn, 2012.

32 F. H. Stootman, D. M. Fisher, A. Rodger and J. R. AldrichWright, Analyst, 2006, 131, 1145-1151.

33 A. de Cian, L. Guittat, M. Kaiser, B. Saccà, S. Amrane, A. Bourdoncle, P. Alberti, M.-P. Teulade-Fichou, L. Lacroix and J.-L. Mergny, Methods, 2007, 42, 183-195.

34 K. Benner, H. Ihmels, S. Kölsch and P. M. Pithan, Org. Biomol. Chem., 2014, 12, 1725-1734. 
35 Y. He, R. D. Neumann and I. G. Panyutin, Nucleic Acids Res., 2004, 32, 5359-5367.

36 K. W. Lim, S. Amrane, S. Bouaziz, W. Xu, Y. Mu, D. J. Patel, K. N. Luu and A. T. Phan, J. Am. Chem. Soc., 2009, 131, 43014309.

37 Nucleic Acids in Chemistry and Biology, ed. G. M. Blackburn, M. J. Gait, D. Loakes and D. M. Williams, Royal Society of Chemistry, Cambridge, 2006, pp. 341-382.
38 R. N. Dsouza, U. Pischel and W. M. Nau, Chem. Rev., 2011, 111, 7941-7980.

39 K. Faulhaber, A. Granzhan, H. Ihmels, D. Otto, L. Thomas and S. Wells, Photochem. Photobiol. Sci., 2011, 10, 1535-1545.

40 (a) F. Wu, Y. Shao, K. Ma, Q. Cui, G. Liu and S. Xu, Org. Biomol. Chem., 2012, 10, 3300-3307; (b) F. Wu, Y. Sun, Y. Shao, S. Xu, G. Liu, J. Peng, L. Liu and N. Lebedev, PLoS One, 2012, 7, e48251. 